\title{
Wall blocks based on the aggregates from plant wastes
}

\author{
Andrei Dalzhonak ${ }^{1}$, Aliaksandr Bakatovich ${ }^{2}$ \\ Polotsk State University, Blokhin str., 29, Novopolotsk 211440, Belarus

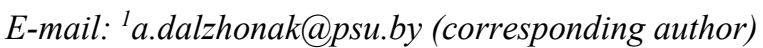

\begin{abstract}
The article considers the possibility of using agricultural waste in the development of new building materials in the form of wall blocks. When selecting the compositions, the ideal fractions and ratios of straw to flax were determined, providing the forming of the densest frame of coarse and fine aggregates. Cement and lime were used as a binder. The effect of humidity on the durability and thermal conductivity of straw wall blocks and straw flax boon blocks were investigated. The conditions for the possible occurrence of mold on the block surface of aggregates were studied. According to the results of full-scale tests, the obtained dependencies of the temperature distribution during the coldest period of the winter season were analyzed and the high insulating ability of wall blocks was confirmed. The dependencies of the distribution of humidity over the thickness of the wall blocks after the end of the winter season testing operations were revealed. As a result of the research, a solution for the rational use of plant waste building wall blocks was proposed. The blocks can be applied to the construction of load-bearing and nonload-bearing walls in one-story buildings and multi-story frame construction when filling exterior wall openings.
\end{abstract}

Keywords: wall blocks, straw, flax boon sustainable materials and their production.

\section{Introduction}

Gradual natural resource depletion and related to this rapid environmental deterioration makes the usage of wastes and secondary products actual while developing new types of construction products. Waste materials from the agricultural industry, such as straw of grain crops and flax boon forms natural resource base. One of the ways of sustainable use of wastes is their application as raw material in the production of wall materials for low-rise urban and rural development. Technologies on plant waste management, the use of plant waste as raw for the production of composite materials is being implemented in many regions. It indicates a high level of interest and relevance of the direction in the sphere of construction. In the industry of construction materials, current energy sources are the largest producers of carbon dioxide. The use of raw material for substituting existing analogues facilitates the solution for environmental pollution. In the process of production of wall material based on the aggregates from plant wastes, emission of carbon dioxide is being reduced and some amount of carbon dioxide is neutralized (Wall, Walker, Gross, White, \& Mander, 2015) because in the process of growing of crops they absorb large quantities of carbon dioxide. There is considerable interest in technical solutions for the development of compositions applying plant aggregates, such as flax boon and straw for exterior wall constructions with increased resistance of heat transfer.

The technology of production of flax boon cement for low-rise cast-in-place construction was developed in Nizhny Novgorod. There gypsum-cement binder and flax boon were used as the main components (Gavrikova, 2006). Suggested development makes it possible to produce flax concrete with a density of $630-980 \mathrm{~kg} / \mathrm{m} 3$ and compressive strength of 0.8-4.4 MPa.

Scientists from O. M. Beketov National University of Urban Economy in Kharkiv also used flax boon as aggregate in developing wall materials (Lobanova \& Kazimagomedov, 2015). Cement was used as a binder and calcium chloride or liquid glass was used to neutralize sugars in flax. Developed wall materials have a density of $480-735 \mathrm{~kg} / \mathrm{m}^{3}$ and resistibility of $0.98-5.4 \mathrm{MPa}$.

The testing of wall materials based on the aggregates from plant wastes was held by scientists from Lublin University of Technology (Barnat-Hunek, Smarzewski, \& Brzyski, 2017). Hemp boon was used as aggregate and lime was used as a binder in the first set of composites. Compressive strength of the specimens was $0.39-0.76 \mathrm{MPa}$, the coefficient of thermal conductivity was $0.09-0.108 \mathrm{~W} /(\mathrm{m} \cdot \mathrm{K})$, bending resistance was $0.12-0.15 \mathrm{MPa}$. In the second set of composites flax boon was used as aggregate. The binder of the composition was a mixture of lime, cement, and

(C) 2019 Authors. Published by VGTU Press. This is an open-access article distributed under the terms of the Creative Commons Attribution (http://creativecommons.org/licenses/by/4.0/) License, which permits unrestricted use, distribution, and reproduction in any medium, provided the original author and source are credited. 
clay. The rates of compressive strength fluctuated between $0.49-0.66 \mathrm{MPa}$, bending resistance was $0.13-0.24 \mathrm{MPa}$ with a thermal conductivity rate of $0.09-0.111 \mathrm{~W} /(\mathrm{m} \cdot \mathrm{K})$.

The research of thermal and technical characteristics of walls made up of hay bales with practical implementation was conducted by scientists from Romania. The average values of conductivity rate were $0.053-0.061 \mathrm{~W} /(\mathrm{m} \cdot \mathrm{K})$. These rates will enable the heat shield of buildings in rural areas (Pruteanu, 2010). At the beginning of 2012 only one strawbale house with wooden frame in Romania was built. After two years, building of 11 houses on the basis of straw material was finished (Cantor \& Manea, 2015). Today the use of straw in building can become an alternative to the use of traditional building materials because they improve the quality of air indoors through their ability to breathe, they also don't produce harmful substances such as formaldehyde. However, it must be noted that the use of straw without mineral binder doesn't provide resulting materials (panels, blocks, etc.) with necessary resistance to rodents' attacks.

At Penza State University of Architecture and Construction, it was suggested to use buckwheat straw as the main building agent for producing wall blocks. The straw was treated with complex mineralizer and had particles not greater than $30-40 \mathrm{~mm}$ in size, which prevented heat convection in intercommunicating pores (Soldatov, 2001). Oat husk in the developed compositions was taken as a fine expanded aggregate. Cement was used as a binder. The material had a density of $544-617 \mathrm{~kg} / \mathrm{m}^{3}$, compressive strength of $0.39-1.32 \mathrm{MPa}$, the coefficient of thermal conductivity was $0.06-$ $0.084 \mathrm{~W} /(\mathrm{m} \cdot \mathrm{K})$.

Rice straw was used as aggregate in the production of cheap building materials for providing housing in Egypt (Mansour, Srebric, \& Burley, 2007). Cement was used as a binder. It is common to utilize straw by burning in Egypt, which in turn leads to environmental deterioration in the region and pollution of the environment. Test results of thermal and technical properties revealed that the blocks can be used as wall or insulating materials in a hot climate.

New technology of production new building materials on the basis of grinned stems of cotton in Tajikistan (Dzhumaev, 2012). Portland cement was used as a binder in the production of the wall materials. The material had compressive strength of $2.9 \mathrm{MPa}$ and a density of $600 \mathrm{~kg} / \mathrm{m}^{3}$, the coefficient of thermal conductivity was $0.116 \mathrm{~W} /(\mathrm{m} \cdot \mathrm{K})$. Calcium chloride and liquid glass were used to prevent the influence of sugars which are contained in stems of cotton on cement.

Research on biocomposite materials based on plant aggregate consisting of rape straw and grinded sunflower stems was conducted by French scientists (Brouard, Belayachi, Hoxha, Méo, \& Abdallah, 2017). Clay was taken as a binder in the developed composition. The rate of density of rape straw biocomposite was $250-420 \mathrm{~kg} / \mathrm{m}^{3}$, the coefficient of thermal conductivity was $0.07-0.08 \mathrm{~W} /(\mathrm{m} \cdot \mathrm{K})$. The use of grinded sunflower stems led to increase in density up to $400-580 \mathrm{~kg} / \mathrm{m}^{3}$ and the thermal conductivity to $0.1-0.14 \mathrm{~W} /(\mathrm{m} \cdot \mathrm{K})$.

Grinded sunflower stems (fraction 1-6 mm) were used in France in the same way to obtain building materials (Mati-Baouche et al., 2014) based on chitosan binder, which is a derivative of chitin. The compositional material had a density of $150 \mathrm{~kg} / \mathrm{m}^{3}$, compressive strength of $2 \mathrm{MPa}$, tension-breaking strength of $2.6 \mathrm{MPa}$ and thermal conductivity of $0.06 \mathrm{~W} /(\mathrm{m} \cdot \mathrm{K})$.

Attention has recently been paid to research of the influence of humidity on operating characteristics of insulation and structural insulating materials. The results of the research determine the choice and application of materials for house building. In the operation process, the moisture content in the materials of cladding structure varies depending on design features, material properties, temperature and humidity indoor conditions, climate conditions on the building territory. Humidity conditions determine technical and performance characteristics of cladding structures, including lasting quality; they also influence the thermal properties of cladding structures and energy efficiency of applied materials.

The importance of the first of the issues has been highlighted by numerous studies devoted to this issue. At the University of Orléans influence of humidity on thermal and technical properties of materials based on sawdust and straw by desiccator method (Belayachi, Hoxha, \& Redikutseva, 2015). To get the insulating materials, complex binder «Tradical PF70» was used. This binder was a mixture of air-hardening lime, lias lime, and pozzolanic material. Absorption humidity of wall materials on the base of millet or barley straw aggregate on lime binder at a relative humidity of $97 \%$ was $23-25 \%$. At the same time when using gypsum as a binder, the rate of absorption humidity was $14-16 \%$. According to the research, they found, that the use of millet or barley straw aggregate didn't have a significant influence on absorption humidity of composite materials. The determining factor is the type of binder.

Scientists of Brest State Technical University elaborated the method of calculation of variable thermohumid fields in cladding structures of buildings taking into account the impact of the environment and material properties. It allows evaluating operation capability when designing the construction of walls (Kofanov, 2013).

In the Faculty's of Civil Engineering laboratory of Polotsk State University we hold the research on the use of raw materials in the development of structural insulating materials. In the paper the research results in the study of wall blocks with high thermal insulation capacity based on agricultural waste such as straw and flax boon. 


\section{Materials and testing methods}

Materials

\section{Coarse and fine aggregate}

In the process of producing wall blocks grinded rye straw was used as coarse aggregate. The straw is largetonnage waste of agricultural production; it looks like long stems left after thrashing. We used cylindrical straw grinder (RSB - 0.1) to get the right length of a stem. The length of the stem was $20-40 \mathrm{~mm}$.

For producing of the wall blocks, flax boon as fine aggregate was used. Flax is a one-year-old plant of the family Linaceae, sown in spring and producing yields in autumn of the same year. Flax boon is major waste after primary processing of flax and makes up $60-70 \%$ of its weight. When the fiber is separated during the process of mint and flutter, the flax stems are being destroyed and the falling lumpy parts form a boon. The particle size of the flax boon particles varies from $1 \mathrm{~mm}$ to $10 \mathrm{~mm}$ in length and $0.3 \mathrm{~mm}$ to $1.5 \mathrm{~mm}$ in thickness.

For experimental research we used flax boon with packed a density of $140-150 \mathrm{~kg} / \mathrm{m}^{3}$. Before the use, flax boon was sifted on a vibration screen $(B A 400 \mathrm{~N})$ with a screen size of $5 \mathrm{~mm}$, the dust was filtered. The fraction of less than $5 \mathrm{~mm}$ made up $50 \%$ of the obtained amount of flax boon.

\section{Binder}

In the process of wall materials development, cement OAO "Krichevcementnoshifer" was used. Requirements are regulated in GOST 31108-2003 (Gosstroy of Russia, 2003). We took bilding lime hydration mixture of II variety as a binder without additives of OAO "Krasnoselskstroimaterialy". Lime is characterized by containing $66 \%$ of $\mathrm{CaO}+\mathrm{MgO}, 3.4 \%$ of $\mathrm{CO}_{2}, 0.7 \%$ of humidity, rest on a sieve is $\mathrm{d}=0.2-0.8 \%$, meets the requirements of STB EN 459 1-2007 (Belorusskij gosudarstvennyj institute standartizacii i sertifikacii, 2007).

\section{Preparation of specimens}

To get raw mix it is necessary to follow the sequence of performing technological operations that are based on experience. They provide equal spread of the components over the body of straw-flax boon blocks. Milk of lime is being mixed with flax boon, and then grinded straw is being carefully mixed with water-cement paste. During the technological procedure of blending straw and water-cement, flax boon partially soaks up the milk of lime. In the next phase, two prepared raw mixtures are being mixed together. As the result, intimate mixture with a homogeneous distribution of flax boon without blobs in the structure of aggregate and binder is obtained. The mixture is being poured into a mold and compacted. Remolding of specimens is being under pressure. The specimens are then removed in 24 hours and have been stored for 28 days in natural conditions at a temperature of $20 \pm 2{ }^{\circ} \mathrm{C}$ and relative air humidity of $60-70 \%$. Material consumption per $1 \mathrm{~m}^{3}$ is $289 \mathrm{~kg}$ of cement, $71 \mathrm{~kg}$ of lime, $94 \mathrm{~kg}$ of straw and $76 \mathrm{~kg}$ of flax boon.

\section{Testing methods}

Density, compression strength is the basic physicomechanical properties of wall materials. They were determined in accordance with GOST 19222-84 (State Committee of the Council of Ministers of the USSR for Construction, 1985).

\section{Determination of thermal conductivity}

The thermal conductivity of the investigated materials was measured according to STB 1618-2006 (Belorusskij gosudarstvennyj institute standartizacii i sertifikacii, 2006).

\section{Water characteristics Curve (Sorption Isotherms)}

Absorption humidity of wall material specimens was determined according to GOST 24816-2014 (Materialy stroitelnye, 2014). After specimens with straw and straw-flax boon mixture aggregate were selected from wall blocks and dried to constant weight, they were placed in desiccator. Steam-air medium in desiccator was created artificially with the help of solution of sulfuric acid of different concentration, which provided relative air humidity of 40-97\%. The humidity of specimens was measured by weighing them every 15 days during the first 2 months of tests, then every 10 days until they reached a constant mass using electronic balance (BK - 300). After defining absorption humidity of specimens' air temperature in desiccator was $+20 \pm 0.5^{\circ} \mathrm{C}$.

\section{Effect of humidity on the thermal conductivity}

Due to the fact that there is no standard procedure of determination of the dependence of the thermal conductivity from humidity in normative documents, we have used procedure applied by Davydenko N.V. in the research of insulating raw materials (Bakatovich, Davydenko, \& Gaspar, 2018).

To define the influence of humidity on the thermal conductivity coefficient of wall blocks, the specimens based on straw and a mixture of straw and flax boon were made in the form of plates, their size was $250 \times 250 \times 30 \mathrm{~mm}$. At the age of 28 days the specimens were dried in a chamber drier until they reached a constant mass, than the coefficient of thermal conductivity was measured using the equipment ITP-MG4. Then the specimens were stored in tight chamber 
on a grating above the water for certain time $(2,5,10,25,60$ days). The longest time duration in the chamber (60 days) is conditioned by reaching the specimens the maximum moisture saturation. During the given period of time hydraulic hitch provides imperviousness and maintains relative humidity in the chamber of $97 \%$. By the end of the period density and the coefficient of the thermal conductivity of the specimens in humid condition were measured.

\section{Laboratorial test results}

\section{Factors influencing the forming of the structure of wall blocks}

Determination of the appropriate ratio of aggregates and expenditure of the binder was done at an early stage of the research. Based on obtained data it was found that at a density of $530-630 \mathrm{~kg} / \mathrm{m}^{3}$ compression strength of the blocks was $2-2.2 \mathrm{MPa}$ and the coefficient of thermal conductivity was $0.075-0.085 \mathrm{~W} /(\mathrm{m} \cdot \mathrm{K})$ in a dry condition. With an increase of the density of wall blocks through increase in expenditure of the aggregate, the time of storing increased up to 4 days, which, in its turn, substantially reduced the amount of cycles of turnover the forms. Removing the specimens from the mold ahead of schedule led to deformation of the specimens in volume. Deconsolidation occurred through completely recoverable straw deformation and inadequate strength of the binder at the time of demolding. Flax boon filled the space in the straw frame and formed another frame, which prevented air movement in the voids of composition, reducing convective heat transfer, thereby thermal conductivity was either reduced. Furthermore, flax boon has rough surface, which enhanced adhesion of cement brick in comparison to weak cohesive resistance with straw due to occurring of wax foil on the surface. This was supported by the results of the study of straw surface structure which were obtained by the researchers from the Prydniprovska State Academy of Civil Engineering and Architecture (Savickij, Sobinova, Zinkevich, Ozhishhenko, \& Ait, 2015).

In producing the wall materials that were proposed for development and study, it was invited to use lime as an admixture in the rate of $20 \%$ of overall mass of cement to neutralize sugars. Applying of lime makes it possible to reduce negative influence of sugars, produced by flax boon, on the process of cement brick structure formation. Lime occurrence provides the rise of binder-aggregate adhesion and formation of cement-brick compact structure. The patent of the Republic of Belarus № 21884 was obtained as a result of investigation (Bakatovich, Davydenko, Dolzhonok, \& Romanovskij, 2018). Material samples are presented in Figure 1.

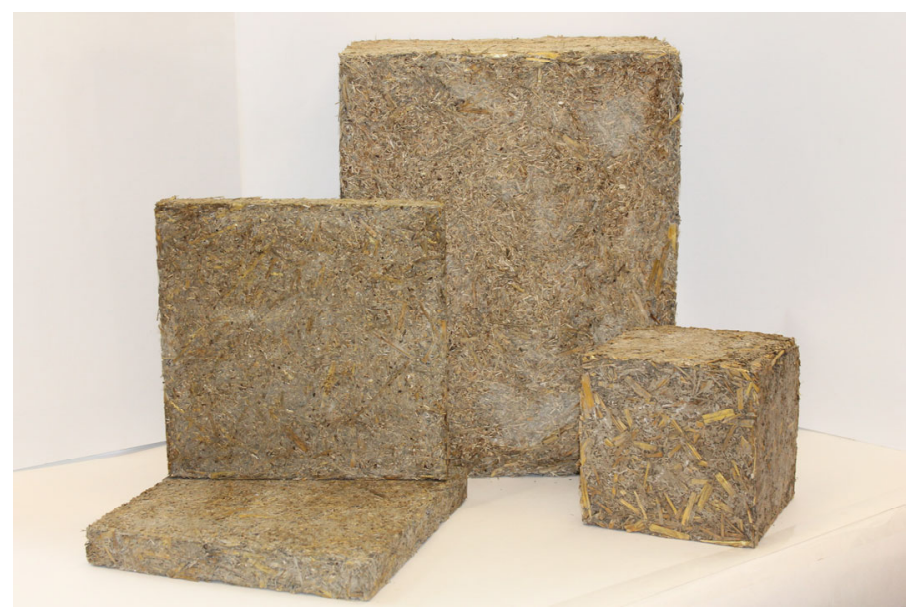

Figure 1. Specimens based on mixture of straw and flax boon

\section{Water characteristic Curve (Sorption Isotherms)}

Absorption humidity of wall blocks was measured with desiccator method. According to the test results, isotherms of water vapour absorption by experimental samples were built (see Figure 2). At relative air humidity of $40 \%$, the humidity absorption of the specimens was $2.4 \%$ in the desiccator. The absorption humidity rate of the specimens based on straw aggregate exceeded by $28 \%$ in comparison to the specimens based on mixture of straw-flax boon aggregate. Blocks based on mixture of straw and flax boon had absorption humidity rate of $3.6 \%$, while blocks based on straw had absorption humidity rate of $3.6 \%$ at a relative air humidity of $60 \%$. Maintaining the relative air humidity level in desiccator at $80 \%$ provided the rise of absorption humidity of specimens based on straw to $5.6 \%$, which is $31 \%$ higher than specimens based on straw and flax boon had. At a relative air humidity of $90 \%$ absorption humidity rate of blocks based on straw and flax boon was $6.7 \%$, while the of humidity of blocks based on straw was $8.1 \%$ which was $21 \%$ higher. At a relative humidity of $97 \%$, absorption humidity of specimens based on straw reached $14.5 \%$, which was $38 \%$ higher than the material based on a mixture of straw and flax boon, equal to $10.5 \%$. 


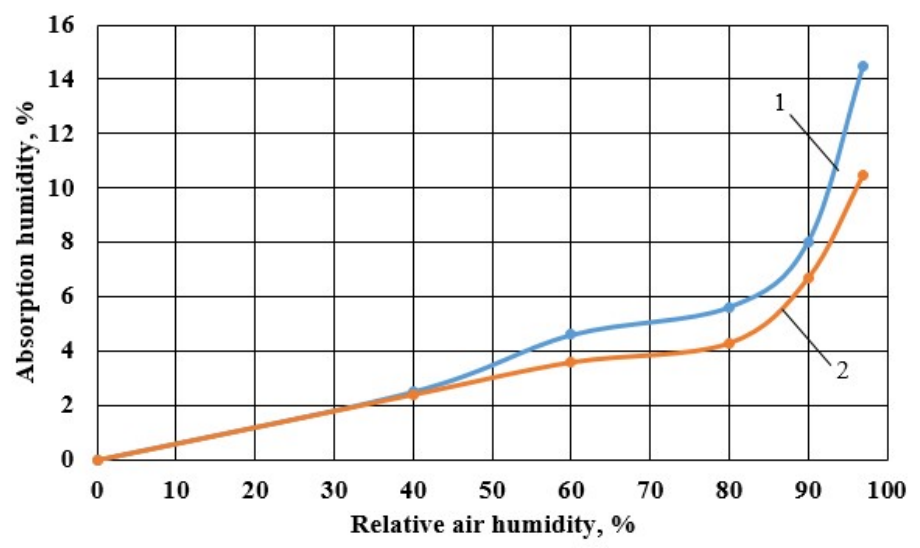

1 - Wall material based on straw; 2 - Wall material based on straw and flax boon

Figure 2. Isotherms of water vapour absorption

Other important material characteristics that provide heat insulation properties of cladding structures include kinetics of water vapor absorption at certain rate of relative air humidity. Kinetics of water vapor absorption by specimens that were chosen from experimental wall blocks is presented in Figures 3-7.

At the relative air humidity of $40 \%$ the rate of absorption humidity of straw and flax boon specimens increased during the first 30 days up to $1.98 \%$, that was $10 \%$ less than the rate of straw specimens over the same period of time. The highest rate of sorption humidity of specimens based on straw was $2.5 \%$ at the age of 68 days. For the specimens based on straw and flax boon the highest rate of sorption humidity was $2.4 \%$ at the age of 80 days (see Figure 3 ).

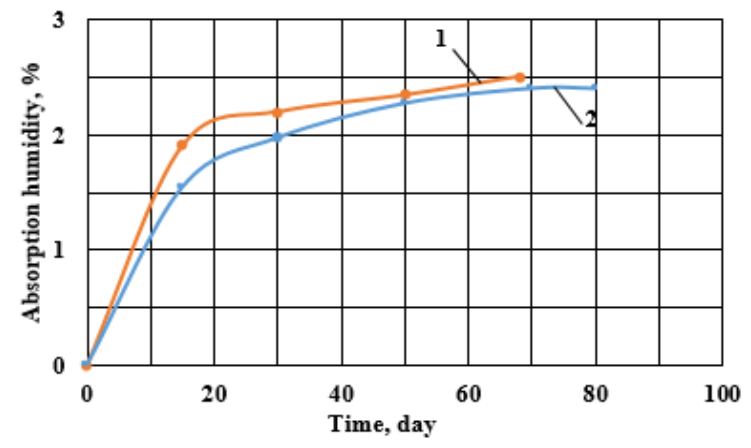

$\rightarrow 1-$ Specimens based on straw

2 - Specimens, based on mixture of straw and flax boon

Figure 3. Kinetics of water vapor absorption by specimens at relative air humidity of $40 \%$

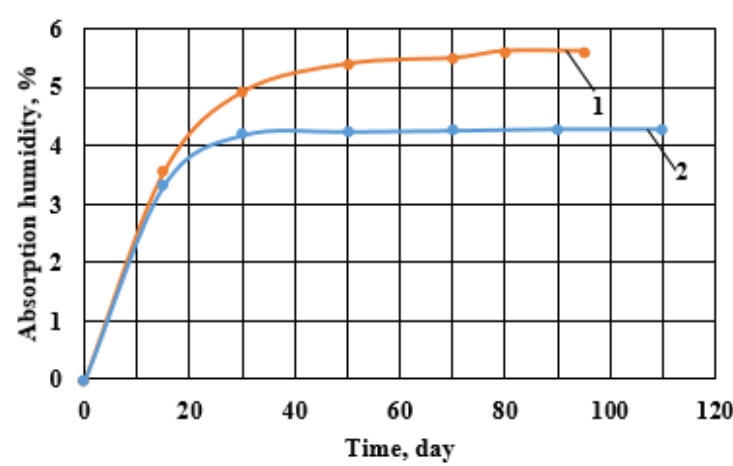

$\rightarrow-1$ - Specimens based on straw

$\rightarrow 2$ - Specimens, based on mixture of straw and flax boon

Figure 5. Kinetics of water vapor absorption by specimens at relative air humidity of $80 \%$

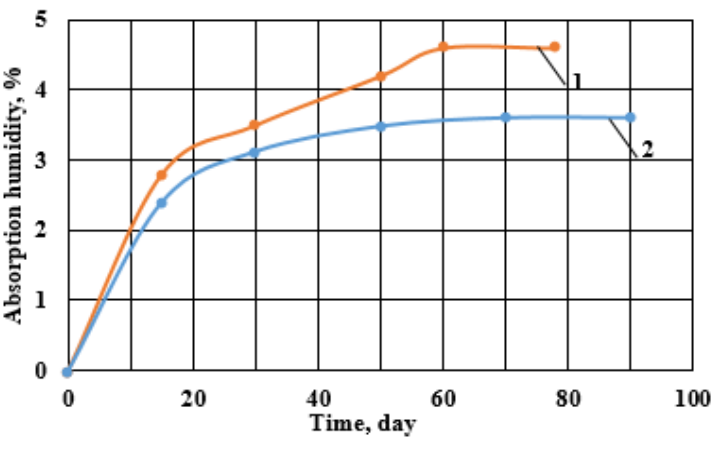

-1 - Specimens based on straw

$\rightarrow-2$ - Specimens, based on mixture of straw and flax boon

Figure 4. Kinetics of water vapor absorption by specimens at relative air humidity of $60 \%$

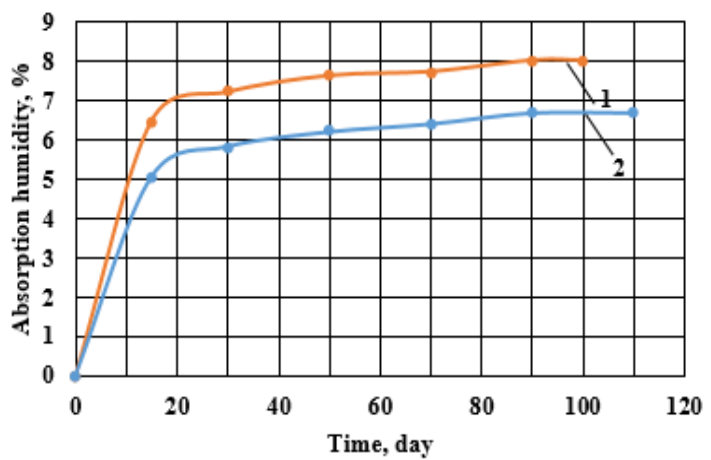

-1 - Specimens based on straw

$\rightarrow-2$ - Specimens, based on mixture of straw and flax boon

Figure 6 . Kinetics of water vapor absorption by specimens at relative air humidity of $90 \%$ 


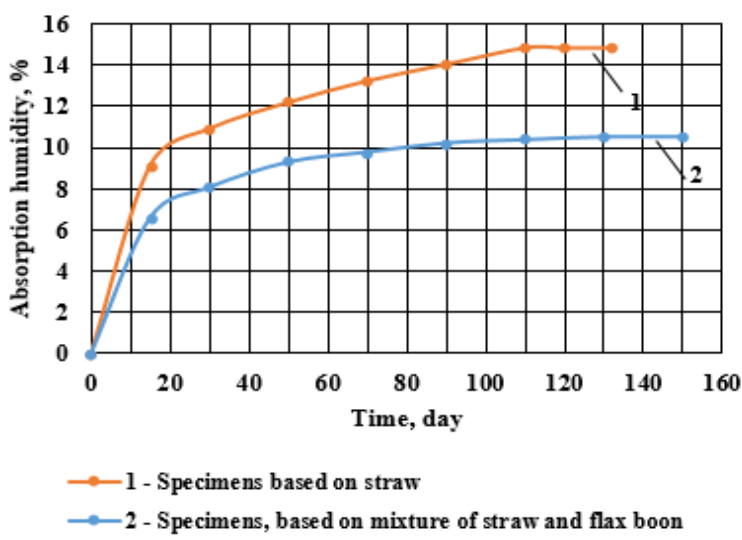

Figure 7. Kinetics of water vapor absorption by specimens at relative air humidity of $97 \%$

At relative air humidity of $60 \%$ the rate of absorption humidity increased during the first 30 days (see Figure 4). The rate of absorption humidity of straw specimens in given period of time was $3.5 \%$, which was $13 \%$ higher than the rate of specimens on the base of straw and flax boon. Sorption of water vapour by specimens based on straw continued for 78 days and reached $4.6 \%$, while the period of water vapour sorption by specimens based on straw and flax boon continued up to 90 days and was $3.6 \%$. It has been found that after 78 days, absorption humidity rate of specimens based on straw and flax was $28 \%$ less than it was of specimens based on straw.

Absorption keeps growing during the period of 30 days at a relative air humidity of $80 \%$. Absorption humidity rate of specimens based on straw was $5 \%$ which is $22 \%$ higher than absorption humidity rate of straw and flax boon specimens. It was determined that maximum absorption humidity rate during 95 days of straw based specimens was $31 \%$ higher than that of straw and flax boon based specimens during the same period and was equal to $4.3 \%$. The absorption period of specimens based on straw and flax boon lasted 110 days (see Figure 5).

There was a considerable increase in absorption humidity at a relative air humidity of $90 \%$ during the first 30 days (see Figure 6). The humidity rate for specimens based on straw was $7.2 \%$, which is $24 \%$ higher than that for straw and flax boon specimens. It should be noted, that the process of absorption of the straw material lasted for 100 days, which is 10 days shorter than that for the straw-flax boon material. Sorption humidity rate of straw specimens was $8.0 \%$, which was $20 \%$ higher than that of specimens based on straw and flax boon.

A rapid increase in absorption humidity for both types of specimens was noticed in the first 30 days at a relative air humidity of $97 \%$. In this, the rate of absorption humidity of straw specimens was $10.9 \%$ which is $35 \%$ higher than the rate of absorption humidity of straw-flax boon specimens. Duration of sorption of straw materials was 132 days, which is 18 days shorter than for straw-flax boon materials. Absorption humidity rates for materials based on straw, and materials based on mixture of straw and flax boon were $14.5 \%$ and $10.5 \%$ respectively (see Figure 7 ). It should be noticed that at the end of the water vapor absorption process absorption humidity rate of straw-flax boon materials was $41 \%$ less than that of materials based on straw. After the end of the absorption process, stabilization of water vapor absorption by the material was observed in all cases.

Additional research was held to determine absorption humidity of grinded straw and flax boon in bulk condition in a chamber above the water at a relative humidity of $97 \%$. Research showed that the rate of absorption humidity reached the maximum value equal to $35 \%$ in 15 days, while humidity limit rate was $10-12 \%$ only in the $9^{\text {th }}$ day at a temperature of $+20^{\circ} \mathrm{C}$. Obtained results were confirmed by researchers from Russian State Agrarian University (Barykina \& Belopuhov, 2016). It was determined that absorption humidity of flax boon depends on the size of particles. Absorption humidity rate was $15 \%$ for flax boon having the length of 5-18 mm and diameter of $1.5-1.8 \mathrm{~mm}$, while for grinded flax boon of $1.5 \mathrm{~mm}$ fraction, absorption humidity rate increased to $17 \%$. Thus, it can be stated that if you replace a part of straw with flax boon, the process of sorption of vapour water in the wall blocks will slow down. Decrease in absorption humidity rate in specimens based on straw and flax mixture, was conditioned by lower rate of absorption humidity of flax boon specimens.

After the absorption process had been studied, the specimens were left in desiccators at a relative air humidity of $80 \%, 90 \%, 97 \%$, so that it could be possible to determine visually the time of molds appearance on the specimens surface. Appearance of molds was fixed on the straw specimens in the 140-day period at a relative air humidity of $97 \%$. In the 180-day period molds were fixed on straw-flax boon specimens. At a relative humidity of $90 \%$ molds appeared on straw material surface in the 170-day period. In 240 days at a relative air humidity of $90 \%$ molds on straw flax boon specimens disappeared and tests were finished. Conditioning of the specimens in desiccators during 240 days at a relative air humidity of $80 \%$ didn't lead to appearance of any molds on the surface. 


\section{Effect of humidity on the thermal conductivity}

The coefficients of thermal conductivity for the materials based on straw (compositions 1-5) and mixture of straw and flax boon (compositions 6-10) in a dry state were $0.085 \mathrm{~W} /(\mathrm{m} \cdot \mathrm{K})$ and $0.075 \mathrm{~W} /(\mathrm{m} \cdot \mathrm{K})$ respectively. The density of specimens was $530 \mathrm{~kg} / \mathrm{m}^{3}$. The results are shown in Table 1.

Tests carried out, that during the first 2 days the density of straw materials (composition 1) increased by $20 \mathrm{~kg} / \mathrm{m}^{3}$, the coefficient of thermal conductivity increased by $0.005 \mathrm{~W} /(\mathrm{m} \cdot \mathrm{K})$, the humidity rate was $3.8 \%$. Density rate of straw flax boon specimens (composition 6) increase by $10 \mathrm{~kg} / \mathrm{m}^{3}$ at a relative humidity rate of $1.9 \%$, the coefficient of thermal conductivity increased slightly by $0.004 \mathrm{~W} /(\mathrm{m} \cdot \mathrm{K})$. Humidity rate of composition 1 with regard to humidity rate of composition 6 doubled, and the coefficient of thermal conductivity of straw materials was $14 \%$ higher, than the rate of materials based on straw and flax boon.

After the analysis of obtained results, it has been stated, that the process of intensive increase in humidity rate occurred during the first 10 days. Humidity rate of composition 3 doubled during the first 2 days and was equal to $7.5 \%$, in comparison to the humidity rate of composition 1 , the coefficient of thermal conductivity increased by $17 \%$. Humidity rate of straw-flax boon material (composition 8) reached $6 \%$ that was 3.2 times higher than in composition 6 at the age of 2 days, at the same time, the coefficient of thermal conductivity increased in $16.5 \%$. At the age of 10 days the coefficient of thermal conductivity of materials based on straw and mixture of straw and flax boon increased in $25 \%$ and $23 \%$ regarding to the rates in a dry state.

Table 1. Rates of density, humidity and thermal conductivity of the wall blocks

\begin{tabular}{|c|c|c|c|c|c|c|}
\hline \multirow[b]{2}{*}{ 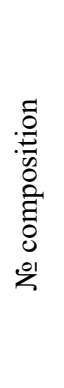 } & \multirow[b]{2}{*}{ Type of aggregate } & \multirow[b]{2}{*}{$\begin{array}{l}\text { Time of keeping } \\
\text { the specimen in } \\
\text { a chamber, days }\end{array}$} & \multicolumn{3}{|c|}{$\begin{array}{l}\text { The rate of the specimen } \\
\text { in wet condition }\end{array}$} & \multirow[b]{2}{*}{$\begin{array}{l}\text { Coefficient of thermal } \\
\text { conductivity variation }\end{array}$} \\
\hline & & & 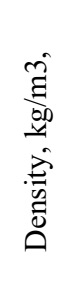 & 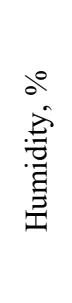 & 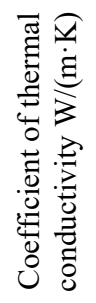 & \\
\hline 1 & \multirow{5}{*}{ Straw } & 2 & 550 & 3.8 & 0.09 & 1.059 \\
\hline 2 & & 5 & 562 & 6.1 & 0.098 & 1.153 \\
\hline 3 & & 10 & 570 & 7.5 & 0.106 & 1.247 \\
\hline 4 & & 25 & 594 & 12.1 & 0.112 & 1.318 \\
\hline 5 & & 60 & 608 & 14.8 & 0.119 & 1.4 \\
\hline 6 & \multirow{5}{*}{$\begin{array}{l}\text { Mixture of straw } \\
\text { and flax }\end{array}$} & 2 & 540 & 1.9 & 0.079 & 1.053 \\
\hline 7 & & 5 & 548 & 3.4 & 0.086 & 1.147 \\
\hline 8 & & 10 & 557 & 6.0 & 0.092 & 1.227 \\
\hline 9 & & 25 & 577 & 8.9 & 0.097 & 1.293 \\
\hline 10 & & 60 & 588 & 10.9 & 0.104 & 1.387 \\
\hline
\end{tabular}

It was also stated, that after 10-days period of keeping both types of specimens in a chamber the difference in rates between them stayed the same. The humidity rate of composition 3 increased by $25 \%$ in comparison to the rate of composition 8 , the coefficient of thermal conductivity increased by $22 \%$.

After the specimens reached maximum water saturation in 60 days, the humidity rate of composition 5 doubled in comparison to the rate of composition 3 which was stored during 10 days, and in 3.9 times in comparison to the composition 1 which was stored during 2 days. Density increment reached $38 \mathrm{~kg} / \mathrm{m}^{3}$ and $58 \mathrm{~kg} / \mathrm{m}^{3}$, the coefficient of thermal conductivity increased by $12 \%$ and $32 \%$ in comparison to the compositions 3 and 1 respectively. The humidity of straw-flax boon materials of composition 10 was in 1.8 times higher than of composition 8 , and in 5.7 times higher than of the composition 6 . If to compare the rates of compositions 8 and 6 , the increase in density of straw-flax boon specimens was fixed by $31 \mathrm{~kg} / \mathrm{m}^{3}$ and $48 \mathrm{~kg} / \mathrm{m}^{3}$, the coefficient of thermal conductivity increased by $13 \%$ and $32 \%$.

Density rate of straw specimens stored in a chamber during 60 days (composition 5) exceeded the density rate of specimen 10 by $20 \mathrm{~kg} / \mathrm{m}^{3}$ and the rate of humidity by $36 \%$. As follows from the results of the test (see Table 1), after 60 days of experiment the coefficient of thermal conductivity of straw-flax boon specimens (composition 10) is equal to $0.104 \mathrm{~W} /(\mathrm{m} \cdot \mathrm{K})$, which is $15 \%$ less than that of composition 5 (straw specimen) equal to $0.119 \mathrm{~W} /(\mathrm{m} \cdot \mathrm{K}$ ). 
In the process of molding of wall materials based on grinded straw we observed rumpling and deformation of straw stems throughout the entire volume of aggregate. It led to the break of the integrity of outer cover and microstructure of the aggregate. Local disruption of outer protecting layer and microstructure contributes to the increase of absorption process by straw tubes.

The use of flax boon as fine aggregate implies decrease in amount of straw-flax boon mixture in comparison to the amount of straw aggregate in bulk condition. It provides rumpling only straw tubes having a diameter of 3-5 mm, while tubes having diameter less than $3 \mathrm{~mm}$ are not deformed and don't have any structure damage in the process of block molding.

Presence of undamaged straw tubes in straw-flax frame in the amount of $40-50 \%$ of the mass of coarse aggregate provides the reduction of water vapor absorption by wall blocks based on mixture of straw and flax boon.

Straw, by its nature, is organic material and is susceptible to the loss of thermal properties because of moisture influence. As follows from the result of the research (Bainbridge, 1986; A. S. Steen, B. Steen, \& Bainbridge, 1994), the humidity rate equal to $15 \%$ is a boundary when there is no loss in the straw material of thermal properties. Increase of humidity of the straw aggregate to $16 \%$ leads to degeneration on the quality of a straw tube. Scientists from Germany, Austria and Egypt have revealed that exceeding of humidity threshold of $18 \%$ leads to activating of spores existing in straw tubes and appearance of molds (Ashour, Georg, \& Wu, 2011). In the process of research, it was stated, that the highest humidity rate of materials with straw aggregate reached $14.8 \%$ at a relative humidity rate of $97 \%$. Therefore, blocks based on straw can reach boundary conditions for the rate of humidity, which will further provide deterioration of operational characteristics including lasting quality and also cause structural failure of aggregate and set in motion a mechanism of biodeterioration of straw.

After the results of the experiment have been processed, diagrams of dependence of the thermal conductivity ratio on the humidity of wall materials based on straw and mixture of straw and flax were obtained (see Figures 8,9 ).
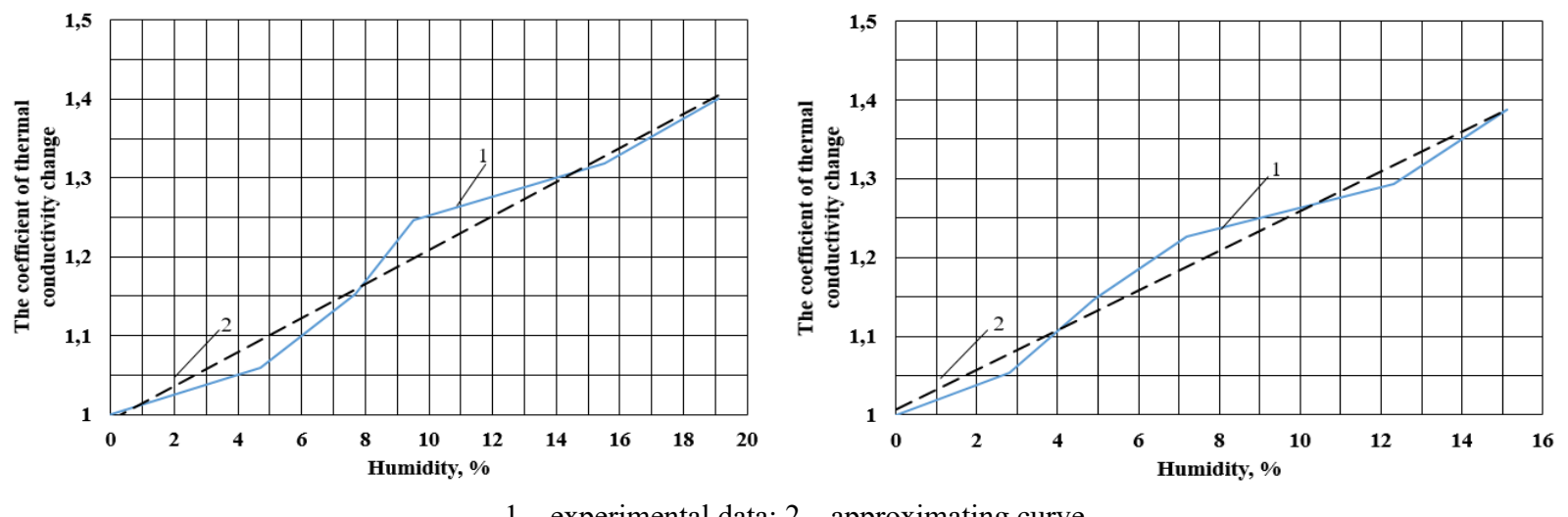

1 - experimental data; 2 - approximating curve

Figure 8. Dependence of the thermal conductivity ratio on the humidity of wall materials based on straw
Figure 9. Dependence of the thermal conductivity ratio on the humidity of wall materials based on straw and flax boon

Analysis of the diagrams according to the data from Table 1 has revealed that the dependence of the coefficient of thermal conductivity rate of wall material on humidity rate was approximated by linear function with relevant correlation coefficient $\mathrm{R}^{2}=0.9783$ for straw specimen and $\mathrm{R}^{2}=0.9861$ for straw-flax boon specimen. On the base of laboratory research and obtained diagrams empirical dependencies 1,2 for materials based on straw or straw-flax boon aggregate were provided:

$$
\begin{aligned}
& \lambda w_{1}=\lambda_{1} \cdot\left(1+0.00279 \cdot W_{1}\right) \\
& \lambda w_{2}=\lambda_{2} \cdot\left(1+0.0354 \cdot W_{2}\right),
\end{aligned}
$$

where $\lambda_{1}, \lambda_{2}-$ is the thermal conductivity of dry wall materials based on straw and straw and flax boon, $\mathrm{W} /(\mathrm{m} \cdot \mathrm{K})$; $W_{1}, W_{2}$ - humidity of the material, \%; $0.0279 ; 0.0354$ - variable coefficient, observed for each wall material; $\lambda w_{1}, \lambda w_{2}$ - thermal conductivity at certain humidity rate, $\mathrm{W} /(\mathrm{m} \cdot \mathrm{K})$.

Obtained empirical dependencies for straw and straw-flax boon wall materials provided the opportunity to predict increase or decrease of the coefficient of thermal conductivity depending on humidity operating conditions of wall building enclosures. One of the necessary requirements for justification of lasting quality and evaluation of the effectiveness of obtained wall blocks was calculated humidity conditions of wall material. Dependencies 1 and 2 can be used for hygrothermal calculation of planned wall enclosures made of blocks based on straw and a mixture of straw and flax boon, and also for justification of technical decisions for effective work of the construction. 


\section{Conclusions}

As a result of the research, we have made straw-flax boon blocks with cement and lime as a binder. The blocks have compressive strength of $2-2.2 \mathrm{MPa}$ at a density of $530-630 \mathrm{~kg} / \mathrm{m}^{3}$. They also have not high coefficient of thermal conductivity equal to $0.075-0.085 \mathrm{~W} /(\mathrm{m} \cdot \mathrm{K})$ in a dry condition.

Data on kinetics of water vapor absorption was obtained after absorption humidity was measured using desiccator method. According to the results, the highest rates of absorption humidity of straw and straw-flax boon blocks are $14.5 \%$ and $10.5 \%$ respectively at a relative air humidity of $97 \%$. Duration of sorption by straw materials is 132 days, the sorption of straw-flax boon materials is 150 days. At a relative air humidity of $60 \%$ absorption humidity of straw materials reached $4.6 \%$ for 78 days, absorption humidity of straw-flax boon materials reached $3.6 \%$ for 90 days. The results enable to calculate humidity conditions of construction and predict the changes of thermal and technical properties and lasting quality of cladding structures made of straw and straw-flax boon blocks in the operation of buildings.

Analysis of effect of humidity on the thermal conductivity of materials in the form of plates has revealed that when using straw and flax boon as aggregates at increasing humidity, the coefficient of thermal conductivity also rises. After the specimens were stored in a chamber the highest humidity rate of materials with straw aggregate reached $14.8 \%$, the coefficient of thermal conductivity increased by $40 \%$ up to $0.119 \mathrm{~W} /(\mathrm{m} \cdot \mathrm{K})$ in 60 days. The highest humidity rate of specimens based on straw and mixture of straw and flax boon was $10.9 \%$, which is $36 \%$ less than that of straw specimens. In this, the coefficient of thermal conductivity increased by $39 \%$ and was equal to $0.104 \mathrm{~W} /(\mathrm{m} \cdot \mathrm{K})$ after the expiry of 60 days. Obtained empirical dependences the coefficient of thermal conductivity on the rate of humidity of wall blocks enable to measure thermal and technical properties of cladding constructions at the design stage in specified conditions and evaluate the effectiveness of work of material insulating capacity. Thus, test data proves, wall blocks based on mixture of straw and flax boon act as load-bearing wall enclosures and provide high thermal insulation properties of external walls.

\section{Reference}

Ashour, T., Georg, H., \& Wu, W. (2011). An experimental investigation on equilibrium moisture content of earth plaster with natural reinforcement fibres for straw bale buildings. Applied Thermal Engineering, 31(2-3), 293-303. https://doi.org/10.1016/j.applthermaleng.2010.09.009

Bainbridge, D. A. (1986) High performance low cost buildings of straw. Agricultural, Ecosystem and Environment, 16(3-4), 281284. https://doi.org/10.1016/0167-8809(86)90009-5

Bakatovich, A. A., Davydenko, N. V., Dolzhonok, A.V., \& Romanovskij, S. A. (2018). Syr'evaja smes' dlja izgotovlenija arbolita (pat. 21884 Resp. Belarus', S 04V 28/00, S 04V 18/24). Aficyjny bjul. Nac. cjentr intjelektual. ulasnasci, $2,97$.

Barnat-Hunek, D., Smarzewski, P., \& Brzyski, P. (2017) Properties of hemp-flax composites for use in the building industry. Journal of Natural Fibers, 14(3), 410-425. https://doi.org/10.1080/15440478.2016.1212764Barykina, J. A., \& Belopuhov, S. L. (2016). Issledovanie sorbcii parov vody celljulozosoderzhashhimi materialami. Izvestija TSHA, 2, 69-75.

Belayachi, N., Hoxha, D., \& Redikutseva, I. (2015). Etude Comparative du comportement hygrothermique des matériaux à base de fibres végétales. Rencontres Universitaires de Génie Civil, Bayonne France.

Belorusskij gosudarstvennyj institute standartizacii i sertifikacii. (2006). Materialy i izdeliya stroitelnye. Metody opredeleniya teploprovodnosti pri stacionarnom teplovom rezhime (STB 1618-2006). Minsk.

Belorusskij gosudarstvennyj institute standartizacii i sertifikacii. (2007). Izvest stroitelnaya. Chast 1. Opredeleniya, trebovaniya $i$ kriterii sootvetstviya (STB EN 459-1-2007). Minsk.

Brouard, Y., Belayachi, N., Hoxha, D., Méo, S., \& Abdallah, W. (2017). Hygrothermal behavior of clay - sunflower (Helianthus annuus) and rape straw (Brassica napus) plaster bio-composites for building insulation. Advanced Engineering Forum, 21, 242-248. https://doi.org/10.4028/www.scientific.net/AEF.21.242

Bakatovich, A., Davydenko, N., \& Gaspar, F. (2018). Thermal insulating plates produced on the basis of vegetable agricultural waste. Energy and Buildings, 180, 72-82. https://doi.org/10.1016/j.enbuild.2018.09.032

Cantor, D. M., \& Manea, D. L. (2015). Using wheat straw in construction. ProEnvironment Promediu, 8(21), 17-23.

Dzhumaev, D. S. (2012). Arbolit na osnove steblej xlopchatnika i texnologicheskie osobennosti ego izgotovleniya. Vestnik KGSTU, $3,10-15$.

Gavrikova, T. A. (2006). Sovershenstvovanie texnologii maloetazhnogo monolitnogo domostroeniya iz kostrobetona (Avtoreferat dissertation candidate technical nauk). Nizhnij Novgorod.

Gosstroy of Russia. (2003). Cementy obshhestroitelnye. Texnicheskie usloviya (GOST 31108-2003). Minsk. Retrieved from http://smy6.ru/images/pdf/GOST31108-2003.pdf

Kofanov, V. A. (2013). Prognozirovanie nestacionarnogo temperaturno-vlazhnostnogo sostoyaniya ograzhdayushhix konstrukcij iz kapillyarno-poristyx materialov (Avtoreferat dissertation candidate technical nauk). Brest.

Lobanova, A. V., \& Kazimagomedov, I. E. (2015). Stenovye izdeliya iz arbolita na osnove kostry lna. Komunalne gospodarstvo mist, 124, 18-20.

Mansour, A., Srebric, J., \& Burley, B. J. (2007). Development of straw-cement composite sustainable building material for lowcost housing in Egypt. Journal of Applied Sciences Research, 3(11), 1571-1580. 
Materialy stroitelnye. Metod opredeleniya ravnovesnoj sorbcionnoj vlazhnosti (GOST 24816-2014). Moskva, 2015. Retrieved from http://protect.gost.ru/v.aspx? control=8\&baseC=-1\&page=0\&month=-1\&year=-1\&search=\&RegNum=1\&DocOnPageCount $=15 \& \mathrm{id}=181140$

Mati-Baouche, N., De Baynast, H., Lebert, A., Sun, S., Lopez-Mingo, C. J. S., Leclaire, P., \& Michaud, P. (2014) Mechanical, thermal and acoustical characterizations of an insulating bio-based composite made from sunflower stalks particles and chitosan. Industrial Crops and Products, 58, 244-250. https://doi.org/10.1016/j.indcrop.2014.04.022

Pruteanu, M. (2010). Investigations regarding the thermal conductivity of straw. Buletinul Institutului Politehnic din lasi, 56, 9-16.

Savickij, N. V., Sobinova, K. S., Zinkevich, O. G., Ozhishhenko, O. A., \& Ait, I. F. (2015). Issledovanie teplofizicheskih svojstv vtorichnyh produktov sel'skohozjajstvennogo proizvodstva organicheskogo proishozhdenija. Stroitel'stvo. Materialovedenie. Mashinostroenie. Serija: Sozdanie vysokotehnologicheskih jekokompleksov v Ukraine na osnove koncepcii sbalansirovannogo (ustojchivogo) razvitija. 81, 217-223.

Soldatov, S. N. (2001). Sozdanie i issledovanie svojstv uteplitelej na osnove mestnogo syrya (Dissertation candidate technical nauk). Penza.

State Committee of the Council of Ministers of the USSR for Construction. (1985). Arbolit i izdeliya iz nego. Obshhie texnicheskie usloviya (GOST 19222-84). Moskva: Izdatel'stvo standartov.

Steen, A. S., Steen, B., \& Bainbridge, D. A. (1994). The straw-bale house. Chelsea Green Publishing.

Wall, K., Walker, P., Gross, C., White, C., \& Mander, T. (2015). Development and testing of a prototype straw bale house. Proceedings of the ICE - Construction Materials, 165(6), 377-384. https://doi.org/10.1680/coma.11.00003 